\title{
Degradation of Lignosulfonate by Fungal Laccase with Low Molecular Mediators
}

\author{
Nam-Seok Cho, ${ }^{*}$ Woonsup Shin, ${ }^{\dagger}$ Seon-Wha Jeong, and A. Leonowicz ${ }^{*}$ \\ School of Forest Resources, Chunghuk Nationat University, Cheongin 361-763, Korea \\ 'Department of Chemistry, Sogang University', Seoul 121-742, Kored \\ ¿Department of Biochemistry, Maria Curie-Sklodowska University, Pl 20031 Lublin. Poland \\ Received Mon:17,2004
}

\begin{abstract}
In the presence of laccase, low molecular weight (M.W.) fractions from lignosulfonate (M.W. $97 \mathrm{~kJ}$ ) were produced. By Sephadex column chromatography, four lower M.W. fractions of $9 \mathrm{kD}, 1.8 \mathrm{kD}, 1 \mathrm{kD}$ and 0.85 $\mathrm{kD}$ were identified. The addition of acetovanillone (AV) or acetosyringone (AS) enhanced to the degradation of lignosulfonate with fungal laccase. During this process, there were found new generation of lower M.W. fractions, e.g. approximately $20 \mathrm{kD}, 1.8 \mathrm{kD}, 1 \mathrm{kD}$ and $0.85 \mathrm{kD}$ for AV, and $20 \mathrm{kD}, 3 \mathrm{kD}, 1 \mathrm{kD}$ and $0.85 \mathrm{kD}$ for AS, respectively. The quantities of lower M.W. products (especially the fractions of M.W. I kD and $0.85 \mathrm{kD}$ ) were larger than those in the controls. Also, its degradation became more active in the presence of AS than AV. The presence of AS or AV seems to prevent the re-polymerization of degraded lignosulfonate by the laccase.
\end{abstract}

Key Words : Lignosulfonate, Laccase, Cerrena unicolor. Mediators, Degradation

\section{Introduction}

Fungal laccases (benzenediol : oxygen oxidoreductases, EC 1.10.3.2) are multicopper inducible oxidases, which are capable of reducing oxygen to water and simultaneously eliminating one-electron from phenolic compounds to give phenoxy radicals. $1-3$ Because of their oxidation capability of phenolic compounds. they are considered as potential industrial enzymes in various applications, such as delignification, ${ }^{+}$wood liber modilication or remediation of contaminated eflluents. 5 Iowever, they have a limited eflect on lignin degradation due to the oxidative specificity. ${ }^{6,7}$ is suggested that the large molecular size of laccase limits the penetration of the enzyme into wood cell wall and lowers the oxidation capability. In the environment of fungal cells, the low molecular weight (M.W.) mediators with high enough redox potential can migrate from the enzymes and oxidize lignin or wood pulp. The satisfying definition of mediators in the context of laccase activity on lignin degradation was formulated that the mediator should have reasonably high redox potential and produce stable cation radical which will transfer electrons from lignin to the enzyme, then to oxygen which is a final electron acceptor in lignin degradation." The schematic explanation of oxygen-laccase-mediator-lignin relationship can be presented (Figure 1).

Consequently, many possible low M.W. compounds have

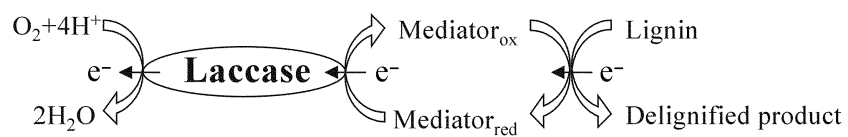

Figure 1. Schematic diagram of lignin degradation by laccasemediator-system (I.MS).

Corresponding Author. Tel: -82-43-261-2542: Fax: -82-43-2732241: e-mail: 17icher 6 , chungbuk.ack been suggested as candidates for a mobile lactor to penetrate to wood cell walls. Some of the metabolites such as veratryl alcohol, oxalate, malate, fumarate, and 3-hydroxyanthranilic acid, are produced by fungi during their metabolism and, duc to secretion of these compounds, enable the fungal colonization concomitant with degradation of wood cell structure. ${ }^{10-13}$ On the other hand, it was reported that delignification of kraft pulp by laccase could be accelerated by some external sources which are neither produced nor present in fungi or pulp. Those are low M.W. compounds or other aromatic hydrogen donors, like 2.2'-azino-bis-(3-cthylbenzenthiazoline-6-sulfonic acid) $(\Lambda \mathrm{BTS})^{1+}$ or 1-hydroxybenzotriazole (IJBT), ${ }^{15}$ which act as mediators. Recently Kim and Shin listed the electrochemical properties of 23 commercially available mediators." They suggested the criteria for the selection of good mediators to have appropriate redox potentials and a good reversibility. However, there are some exception from these criteria, e.g. as mentioned earlier, very good mediator HBT ${ }^{\text {th. } 15}$ possesses too high redox potential with no reversibility.

The ligninolytic activity of Trametes versicolor was studied by livernoche ef $a ._{.} .^{17.18}$ The inducible extracellular laccase of $T$. versicolor slowly degraded the high M.W. fractions of lignosulfonates and possessed both polymerization and depolymerization activity, though the former was predominant. "However, the purified laccase from same fungus did not reduce the lignin contents in hardwood and softwood kraft pulps, ${ }^{20}$ although it produced small amounts of methanol through demethoxylation of lignin. Only in the presence of ABTS, the laccase was able to reduce the pulp lignin. This mediating compound, ABTS, simultaneously prevented and reversed the polymerization of kraft lignin by the laccase enzyme. ${ }^{20}$ Bourbonnais et al. reported in details about delignification of hardwood and softwood kraft pulps with two laccase isozymes purified from $T$. versicolor in the presence of the mediators, ABTS and HBT. ${ }^{1.4}$ Direct Blue 1 
dye was decolorized by culture extracts containing laccase with two mediators, acetosyringone (AS) and methyl syringate. ${ }^{16}$ However, there was no mediator-related report on the Cemena whicolor, which is known fungus as a very good producer of laccase. ${ }^{5.21 .22}$

The low M.W. compounds, acetovanillone (AV) and AS, contrary to ABTS and HBT, could be produced during lignin degradation and much cheaper than ABTS or HBT. This study aimed to examine whether $C$. unicolor laccase can cooperate with $\mathrm{AV}$ and $\mathrm{AS}$ in degradation of high M.W. fraction of lignosulfonate.

\section{Experimentals}

Chemicals. The commercial sodium lignosulfonate of spruce wood origin was obtained from Norcem AS (Oslo, Norway), agar from Junsei Chemical Co. (Tokyo, Japan), malt and yeast extracts from DIFCO (Milwaukee. WI. U.S.A.), syringaldazine (4-hydroxy-3,5-dimethoxy benzaldehydatine), acetovanillone (AV; 4-hydroxy-3-methoxyacetophenone), acetosyringone (AS; 3,5-dimethoxy-4-hydroxyacetophenone), and bovine liver catalase from AldrichChemie (Steinheim, Germany), bovine serum albumin from Sigma (St. L couis, Mo. U.S.A.), DГ.AF: Toyopearl $650 \mathrm{~S}$ from Tosoh Corporation (Tokyo, Japan), Sephadex G-25. Sephadex G-50 'fine', ConA-Sepharose and AH-Sepharose4B from Pharmacia (Uppsala, Sweden), and syringaldehyde from Fluka A.G. (Buchs, Switzerland).

Cultures. Correna anicolor (Bull, ex Fr.) Murr. (MC T 062) was kindly provided from the Molitoris Collection, Institute of Botany, University of Regensburg. Germany. The fungus was maintained on $2 \%$ (wt/vol) malt agar slants. The fungal culture was grown in a basal medium based on Crapek Dox and Lindeberg media containing different amounts of $\mathrm{Na}_{2} \mathrm{HPO}_{4} \mathrm{pH}$ of the medium was adjusted to optimal level by using phosphate buffer. ${ }^{23}$ The media were inoculated with fungal agar plugs $(c a .0 .5 \mathrm{~cm})$. and incubated at $27^{\circ} \mathrm{C}$ till form mycelial mat on surface the media. The mycelial mats were collected and homogenized in a Warring Blender. The shallow stationary culture, after inoculation with $4 \%(\mathrm{rol} / \mathrm{vol})$ of the homogenate, was incubated in $250 \mathrm{~mL}$ conical flasks containing $50 \mathrm{~mL}$ medium and in $1000 \mathrm{~mL}$ flat Roux flasks at $27{ }^{\circ} \mathrm{C}$ for the enzyme.

Determination of Protein. The protein contents of the culture fluids and laccases were determined by the method of Lowry et al.$^{24.29}$ using bovine serum albumin as a standard.

Determination of Laccase Activity. The enzyme activity was measured at $20^{\circ} \mathrm{C}$ with syringaldazine as a substrate according to reaction proposed by Harkin and Obst. ${ }^{25} \mathrm{ME}$ $\mathrm{NaOH}$ buffer utilized by Leonowicz and Grzywnowic $z^{76}$ was replaced by $0.1 \mathrm{M}$ citrate-phosphate buffer. ${ }^{2:}$. To exclude endogenous peroxide, the $10 \mathrm{~min}$. preincubation of the enzyme sample with catalase $\left(10 \mathrm{mg} \cdot \mathrm{mL}^{-1}\right)$ was performed. the activity was expressed as nkat, using molar absorption coefficients of $65,000 \mathrm{M}^{-1} \mathrm{~cm}^{-1}$ at $525 \mathrm{~nm}^{26}$
Isolation and Purification of Laccase. I accase was isolated and purified from the culture filtrates of $C$. unicolor: The ConA-Sepharose column was prepared according to Froehner and Friksson. ${ }^{27}$ The commercial ConA-Sepharose suspended in $0.1 \mathrm{M}$ acetate buffer $(\mathrm{pH} 6)$, containing $0.1 \mathrm{M}$ $\mathrm{NaCl}, 1 \mathrm{mM} \mathrm{CaCl}$ and $1 \mathrm{mM} \mathrm{MgCl}$, was packed into a column of $15 \times 1.5 \mathrm{~cm}$. Before use, the column was washed with 2 volumes of $0.1 \mathrm{M}$ phosphate buffer $(\mathrm{pH} 6)$, and equilibrated with the same buffer. AH-Sepharose $4 \mathrm{~B}$ coupled to syringaldehyde was used in affinity chromatography, ${ }^{\text {?3 }}$ The coupling procedure was performed by the method of Paszczynski and Trojanowski, ${ }^{28}$ but veratraldehyde was replaced by syringaldehyde (Figure 2).

The obtained column beds were suspended in $0.5 \mathrm{M} \mathrm{NaCl}$. washed with 2 volumes of $0.1 \mathrm{M}$ phosphate buffer $(\mathrm{pH} 6)$, and equilibrated with the same buffer. For the $C$. unicolor laccase purification, the methods of leonowicz ef al. ${ }^{21}$ and Gianfredat of $a l^{2 z}$ were used. Some modification was applied as follows. The aerated cultures at the tops of laccase activity were filtered through Miracloth (Calbiochem, Iucerne, Switzerland). Fach filtrate was desalted on the Sephadex G25 column. The enzyme solution was concentrated to $c a$. one tenth of the volume at $4{ }^{\circ} \mathrm{C}$ with an Amicon ultrafiltration system equipped with a filter type PTGC (pore size 10.000 NMW1.) and dialyzed 7 times to the deionized water and 0.1 $M$ phosphate buffer ( $\mathrm{pH} 6$ ) before the end of dialysis. Then $25 \mathrm{~mL}$, portions of enzyme were applied onto the ConASepharose columns $(7 \times 1.5 \mathrm{~cm})$, which were then washed with $0.1 \mathrm{M}$ phosphate buffer, until all unbound proteins were removed. The specifically bound proteins, including laccase, were eluted from the column with $10 \% \alpha$-methyl-mannoside in $0.1 \mathrm{M}$ phosphate buffer $(\mathrm{pH} 6)$. The fraction showing the highest laccase activity was concentrated by ultrafiltration, poured onto DГАГ-Toyopearl column $(25 \times 1.5 \mathrm{~cm})$ and eluted by a linear gradient of $0-0.35 \mathrm{M} \mathrm{NaCl}$ in $5 \mathrm{mM}$ Tris/ $\mathrm{HCl}$ buffer $(\mathrm{pH} 6.0)$. The fraction with high laccase activity was collected, dialyzed to $0.5 \mathrm{mM}$ Tris/ $\mathrm{HCl}$ buffer $(\mathrm{pH} 6)$ and applied onto a column of $\mathrm{AH}$-sepharose $4 \mathrm{~B}$ coupled to syringaldehyde. The enzyme was eluted by $0.5 \mathrm{M}$ ammonium sulphate dissolved in the same buffer $(\mathrm{pH} \mathrm{6.0)}$, and stored as freeze-dried.

Fractionation of Lignosulfonate. Lignosulfonate was fractionated on a Sephadex G-50 column $(185 \times 2 \mathrm{~cm})$. Each time $75 \mathrm{mg}$ of lignosulfonate dissolved in $1.5 \mathrm{~mL}$ distilled

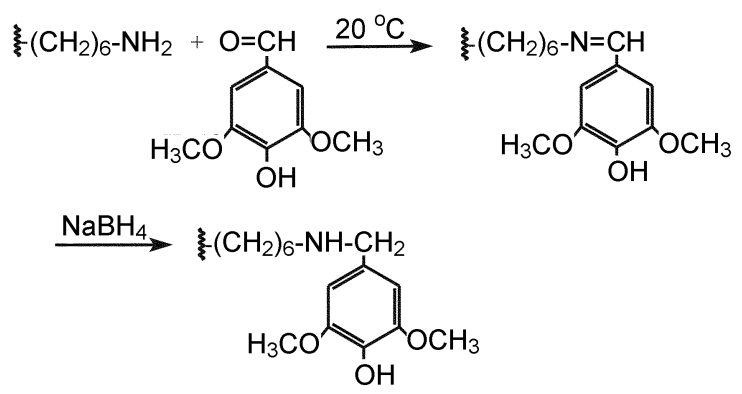

Figure 2. Scheme of coupling of AlI-Sepharose 413 to syringaldehyde. 
water was fractionated. The samples $(3 \mathrm{ml}$.) were eluted with $\mathrm{H}_{2} \mathrm{O}$ (flow rate $0.5 \mathrm{ml} \cdot \mathrm{min}^{-1}$ ) and the $\mathrm{A}_{283}$ was read against water as blank. The fraction of molecular weight 97 $\mathrm{kD}$ was collected, concentrated, and lyophilized. The molecular weights were determined by gel-permeation chromatography with protein kits (Pharmacia, Uppsala. Sweden). ${ }^{(1)}$

Incubation of Lignosulfonate with Laccase. The procedure was partly based on the report of l.eonowicz ot al.$^{19}$ as follows. The lignosulfonate at a concentration of 1 $\mathrm{mg} \cdot \mathrm{mL}^{-1}$ was incubated with laccase $\left(3,2 \mathrm{nkat} \mathrm{mL}^{-1}\right)$ and $\mathrm{AV}$ or AS $(1.0 \mathrm{mM})$ in $10 \mathrm{ml}$. of $0.1 \mathrm{M}$ citrate-phosphate buffer $(\mathrm{pH} 5.0)$ at $27^{\circ} \mathrm{C}$. After $120 \mathrm{~min}$, the reaction was stopped by acidifying the mixture by adjusting to $\mathrm{pH} 1.5$. Controls containing the boiled laccase $(30 \mathrm{~min})$ were prepared same way. The reaction mixture $(5 \mathrm{ml}$.) was applied onto a Sephadex G-50 fine or superfine column, and eluted. Products were detected as described I eonowicz et $a l^{19}$ Fluted fractions were collected, and their molecular weights were determined.

\section{Results and Discussion}

The C. unicolor extracellular laccase was isolated and purified from the shallow stationary culture by following procedures based on ion-exchange chromatography on the DE:AE:-Toyopearl column and atfinity chromatography on the ConA-Sepharose and Syringyl-AH-Sepharose 4B. Through these procedures, a little more than 100 -fold purified laccase was obtained (Table 1).

Based on the fractionation of lignosulfonate on Sephadex G-50 fine column, the fraction having average M.W. of 97 $\mathrm{kD}$ was used for further experiments. The laccase with lignosulfonate was dark-yellow opalescent color in the reaction mixture, In the presence of laccase, four M.W. fractions of average M.W. of $9 \mathrm{kD}, 1.8 \mathrm{kD}, 1 \mathrm{kD}$ and 0.85 $\mathrm{kD}$ from high M.W. lignosulfonate (M.W. $97 \mathrm{kD}$ ) were identified (Figure 3). This result is compatible to earlier reports of Leonowicz et $\mathrm{al}^{6.19}$

In order to speculate the cooperative reaction of laccase and mediators, AS and AV, on lignin degradation, the effect of $A S$ and $A V$ addition on lignosulfonate degradation was examined by means of Sephadex G-50 superfine column. Figure 4 shows the addition of the mediator caused a

Table 1. Isolation and purification of laccase from $C$. unicolor

\begin{tabular}{|c|c|c|c|c|}
\hline $\begin{array}{c}\text { Purilication } \\
\text { step }\end{array}$ & $\begin{array}{c}\text { lotal } \\
\text { activity } \\
\text { (t) herrol) }\end{array}$ & $\begin{array}{c}\text { Specilic } \\
\text { activity } \\
\text { (total/me protcin) }\end{array}$ & $\begin{array}{l}\text { Yield } \\
(\%)\end{array}$ & $\begin{array}{l}\text { P'urilication } \\
\text { factor } \\
\text { (fold) }\end{array}$ \\
\hline Filtrate & 74.278 & 51 & 100.0 & 1.0 \\
\hline Sephadex (j-25 & 56.431 & 94 & 76.0 & 1.8 \\
\hline 1.]trafiltration & 47.373 & 187 & 63.8 & 3.7 \\
\hline ConA-Sepharose & 38.292 & 1.991 & 51.6 & 39.0 \\
\hline DEAE-Toyopear] & 10.127 & 3.462 & 13.6 & 67.9 \\
\hline $\begin{array}{l}\text { Syringyl-AH- } \\
\text { Sepharose 4B }\end{array}$ & 5.634 & 5.195 & 7.6 & 101.9 \\
\hline
\end{tabular}

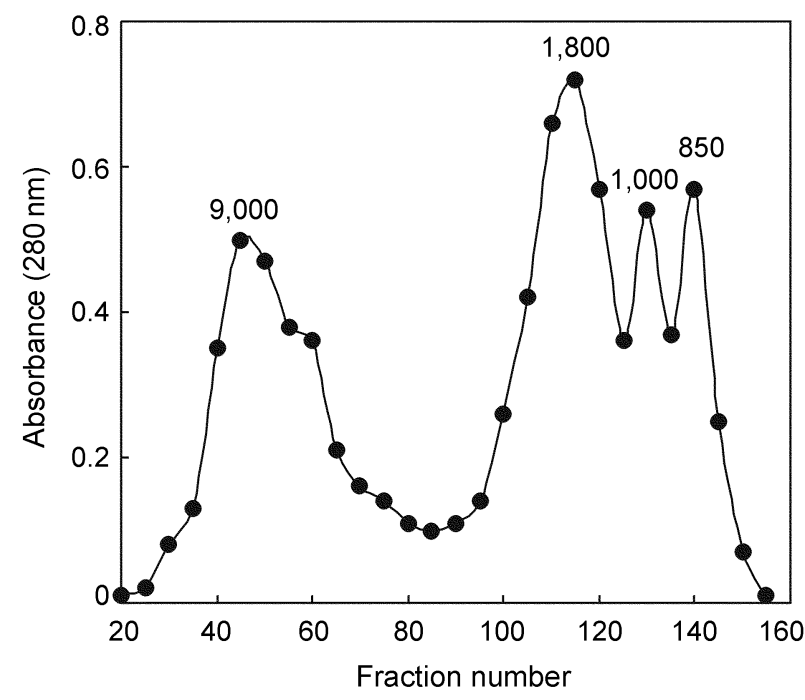

Figure 3. Fractionation of lignosultonate on Sephadex ( $\mathrm{i}-50$ line column $(185 \times 2.0 \mathrm{~cm})$ adter incubalion with laccase. The number on the peak represents the molecular wejght of each fraction.

quantative decrease in ligh M.W. of lignosulfonate and new generation of lower M.W. fractions, e.g. approximately 20 $\mathrm{kD}, 1.8 \mathrm{kD}, 1 \mathrm{kD}$ and $0.85 \mathrm{kD}$ for $\mathrm{AV}$, and $20 \mathrm{kD}, 3 \mathrm{kD}, 1 \mathrm{kD}$ and $0.85 \mathrm{kD}$ for AS, respectively. The guantities of lower $\mathrm{M} . \mathrm{W}$. products (especially the fractions of M.W. $1 \mathrm{kD}$ and $0.85 \mathrm{kD}$ ) were generally larger than those in the controls. Moreover AS found to be superior to enhance this reaction than that of AV. The control experimental data with laccase only (solid circle in Figure 4) are a little different from those in Figure 3. where the column was G- 50 tine instead of G-50 superfine.

The presence of AS or AV might lead to different degradation pathway and prevent the reversed polymerization of lignosulfonate by the fungal laccase as explained by

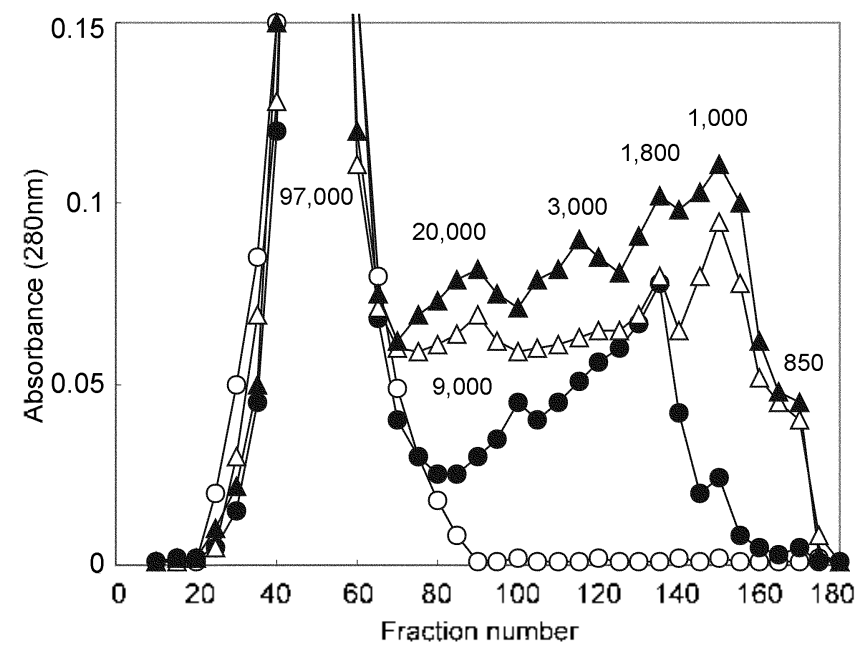

Figure 4. Flution profile of lignosulfonate on Sephadex G-50 superline column $(185 \times 2 \mathrm{~cm})$ atter incubation with lacease and mediators. $\mathrm{AV}=$ acetovanillone: $\mathrm{AS}=$ acetosyringone: $\mathrm{a}$ no laccase: - with lacease: $\therefore$ laccase $-\mathrm{AV} ;$ - lacease + AS. The number on the peak represents the molecular weight of each firaction. 
Bourbonnais et $a l^{2 i j}$ where similar effect observed using laccase and ABTS. Bourbonnais et $a l^{3}$ reported the reduction of lignin contents of hardwood and softwood kraft pulps at $\mathrm{pH} 5$ followed by the alkaline extraction.

The problem whether laccase polymerizes or depolymerizes lignin has been studied for many years. It refers to the different opinions of two groups of authors, the followers (e.g. Ander and Eriksson ${ }^{31 j}$. Kirk et $\left(d{ }^{31}{ }^{31}\right.$ ) and the opponents (e.g. Haars and Huttermann ${ }^{32}$ ) of the hypothesis that laccase causes depolymerization of lignim. It is worthwhile that authors who deny the possibility of depolymerization draw their conclusion from experiments done in vivo. where changes in molecular weights of lignins during the fungal growth were observed. The results mainly based on reports by Ishihara and Miyazaki $i^{\hat{3} 3}$ who were found the double function of the enzyme showed that polymerization dominates over depolymerization. Meanwhile the authors suggested that polymerization and degradation activities of laccase can result from the oxidative ability of the enzyme towards polyphenolic compounds and radicals. ${ }^{33}$ Such phenolic substrates could be produced during the course of its demethoxy lation. Similar function was also described for laccase. ${ }^{, 3,34}$ This degradation could be the first step of lignin biodegradation. ${ }^{3,6}$ Leonowicz et al. ${ }^{19}$ also indicated that polymerization and depolymerization of liguin by the laccase possibly depend on the size of the lignin molecule. e.g. when low M.W. lignin was a substrate of laccase. polymerization was observed, while the opposite process occurred in the case of high M.W. lignin. Probably degradation cannot proceed to the point of yielding considerable amounts of low M.W. compounds because they are repolymerized quickly. The weak degradation effect of lignosulfonate is resulted probably from the fact that main laccase reaction on lignosulfonate proceeds through formation of very active phenoxy radicals inmediately associating each other. The AS and AV oxidized by laccase probably hinder such spontaneous repolymerization, which is a similar phenomenon observed when laccase was applied together with glucose oxidase. ${ }^{6}$ Thus it could be concluded that the $C$. unicolor laccase is able to depolymerize lignosulfonate and mediators (AV and AS) meaningly inproves the process.

Acknowledgement. This work was supported by the Korea Research Foundation Grant (2001-042-G00015).

\section{References}

1. Leonowicz. A.: Trojanowski. J. H/frobios. 1975. 13. 167

2. Thurston. C. F. Aficrobiol 1994, 140. 19.

3. Leonowicz A.: Cho, N.-S.: Luterek. J.: Wilkolazka. A. I.: WojtasWasilewska. M.: Matuszewska. A.: Hofrichter. M.: Wesenberg.
D.: Rogalski. J. J. Basic Afrobiol. 2001. 41. 183

4. Kim. Y: Cho. N.-S.: Eom. T. J.: Shin. W. Bull Konam Chem. Soc. 2002. 23,985

5. Leonowicz, A.; Gianfreda. L.: Rogalski. J.: Jaszek, M.; Luterek, J:- Wojtas-Wasilewskia. M; Malarczyk, E; Dawidowicz, A.; FinkBoots. M.: Ginalska. G.: Staszczak. M.: Cho. N.-S. Mokchae? Konghak 1997. 25. 29.

6. Leonowicz. A.: Rogalski. J.: Taszek. M.: Luterek. J.: WọtasWasilewska, M.; Malarczyk. E.: Ginalski, G.; Fink-Boots. M: Cho. N.-S. Holzforschung 1999. 53.376.

7. Szklarz, G.: Leonowicz, A. Phtochem. 1986. 25.2537.

8. Evans. C. S.: Dulton. M. V.: Guillen. F.: Veness. R. G. FEIS Microbiol. Rev. 1994. 13.235.

9. Kim. Y. S.: Shin. W. S. Proc. Intenat' Sym. For: Sci.: Chungbuk Nat. Univ.: Cheongju, Korea. 2000: p 16.

10. Eggert. C.: Temp, U.: Dean. J. F. D.: Eriksson. K. E. FEBS Lett. 1996. 391, 14t.

11. Hofrichter. M.: Ziegenhagen. D.: Vares. T.: Friedrich. M.: Jager. M. G.: Frische. W.: Hatakki. A. FEBS Lett. 1998. $13+362$.

12. Lundquist. K.: Kirk. T. K. Phytochem. 1978. 17. 1676.

13. Traquair. J. A. Con. J. Bot. $1987,65,1952$.

14. Bourbonnais, R: Paice. M. G.; Freiermuth. B.: Bodie. E: Boememan. S. Appl. Eniron. Aficrobiol 1997. 63.4627.

15. Call. H. P. PCT Forld Pat Appl. WO94:29510. 1994.

16. Schueider. P.: Caspersen. M. B.: Mondorf. K.: Halkier. T.: Sko. L. K: Oestergaard. P. R.: Brown. K. M.: Brown. S. H.: Xu. F. Enzlnte Hichob. Techol. 1999, 25.502.

17. Livernoche. D.: Jurasek, L: Desrochers. M.: Veliky L. A. Biotechnol Lett. $1981,3,701$.

18. Cho. N.-S.: Park. T. M.: Choi. T. H.: Matuszewsha. A.: Jaszek. M.: Grzywnowicz. K.: Malarczyk. E.: Trojanowski. K.: Leonowicz. A. 1lokchae Konghak 1999.27.72.

19. Leonowicz, A.; Szklarz, G.; Wojtas-Wasilewska, M. Phytochent. 1985. 2+393

20. Bourbonnais. R.: Paice, M. G.: Reid. I. D.: Lanthier, P.: Yaguchi, M. Appl Enimon Afichobiol 1995.61. 1876.

21. Leonowicz. A.: Gianfreda. L.: Rogalski. T.: Taszek. M.: Luterek. J.: Wojtas-Wasilewska. M.: Malarezyk. E.: Dawidowicz. A.: Fink-Boots. M.: Ginalska. G.; Cho. N.-S. J. Korea Tappi 1997, 29.7.

22. Gianfreda, L; Sannino. F; Lilazzola. M. T:; Leonowicz. A. $J$. Mol. Cat $1998+13$

23. Bollag. T. M.: Leonowicz. A. Appl. Environ. Horobiol 1984. 18. 849 .

24. Lowly. O. H. N.: Rosebrough. T.: Farr. A. L.: Randall. R. T. J. Biol. Chent $1951,193,458$.

25. Harkin. J. M.: Obst. J. R. Experientia. 1973, 29. 381

26. Leonowicz, A.: Grzywnowicz. K. Enzwme Michobiol. Technol. 1981. 3. 55.

27. Froehner. S. C.: Erikssont. K. E. J. Bacteriol. 1951. 120.458

28. Paszczynski. A.: Trojanowski. J. Afomobios. 1977. 18. 111.

29. Leonowicz, A.: Trojanowski, J; Orlicz. B. Acta Biochm. Polon. 1978. 25,369

30. Ander. P. Eriksson. K. E. Awh Mficrobiol 1976, 109. 1

31. Kirk. T. K.: Harkin. T. M.: Cowling. E. B. Biochim Bioph's. Acta 1968. 165.145 .

32. Haars. A.: Huttermant1. A. Arch Aforobiol 1980. 125. 233.

33. Ishihara, T:; Myazaki, M. Mokuzai Gakkaishi. 1972,18.415.

34. Leonowicz, A.: Rogalski. J; Malarezyk. E; Grzywnowicz. K.; Ginalska, G.; Lobarzewski, J.: Ohga. S.; Pashenova. N.: Lee, S. S: Cho. N.-S. Mokchae Konghak 2000. 28. 29. 